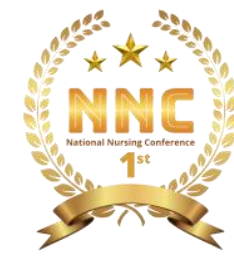

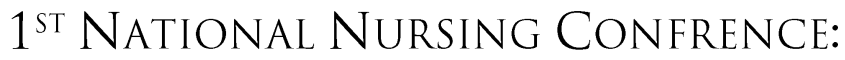

The Sustainable InNovation In Nursing EduCATION

AND PRACTICE

DOI: https://doi.org/10.34305/nnc.v1i1.107

\title{
HUBUNGAN ANTARA POLA MAKAN DENGAN KENAIKAN BERAT BADAN IBU HAMIL DI PUSKESMAS GARAWANGI KABUPATEN KUNINGAN
}

\author{
Ai Nurasiah, Ridha Amalia Sholihati \\ Sekolah Tinggi Ilmu Kesehatan Kuningan Garawangi \\ 41nurasiah@gmail.com
}

\begin{abstract}
Abstrak
Kenaikan berat badan ibu hamil rata-rata $20 \%$ dari berat badan ideal sebelum hamil, tergantung dari tinggi badan dan berat badanya sebelum kehamilan. Kenaikan berat badan disebabkan karena adanya pertumbuhan janin, plasenta dan air ketuban. Kenaikan berat badan salah satunya disebabkan karena pola makan. Pola makan yang salah dapat menyebabkan gangguan gizi pada ibu hamil. Hasil studi pendahuluan di Puskesmas Garawangi dari 9 ibu hamil didapatkan 5 orang mengalami kenaikan kurang dan 4 orang mengalami kenaikan normal. Tujuan penelitian untuk mengetahui hubungan antara pola makan dengan kenaikan berat badan ibu hamil di Puskesmas Garawangi Kabupaten Kuningan. Metode penelitian yang digunakan adalah penelitian survey analitik dengan rancangan retrospektif. Populasi dalam penelitian ini adalah ibu hamil trimester II dan III, Teknik sampel yang digunakan accidental sampling yaitu ibu hamil trimester II dan III pada bulan agustus tahun 2019 berjumlah 30 responden. Instrumen dalam penelitian ini menggunakan kuesioner. Analisis data bivariat dengan menggunakan Rank spearman. Hasil analisis univariat sebagian besar ibu hamil trimester II dan III memiliki pola makan yang kurang baik yaitu sebesar $50 \%$ dan dan sebagian besar ibu hamil mengalami kenaikan berat badan normal yaitu sebesar $46,7 \%$. Hasil analisis bivariat didapatkan nilai $p$ value 0,000 dan nilai $r$ 0,773. Dengan demikian terdapat hubungan antara pola makan dengan kenaikan berat badan pada ibu hamil. Diharapkan Ibu hamil dapat mengatur pola makan dengan menu gizi seimbang dan menu yang bervariasi serta tidak mengkonsumsi makanan cepat saji dan menghindari kebiasaan mengkonsumsi makanan berlemak terutama pada trimester ke II dan III.
\end{abstract}

Kata Kunci: Pola Makan, Kenaikan Berat Badan

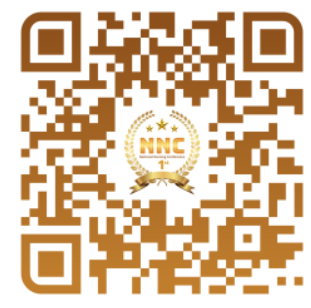

